
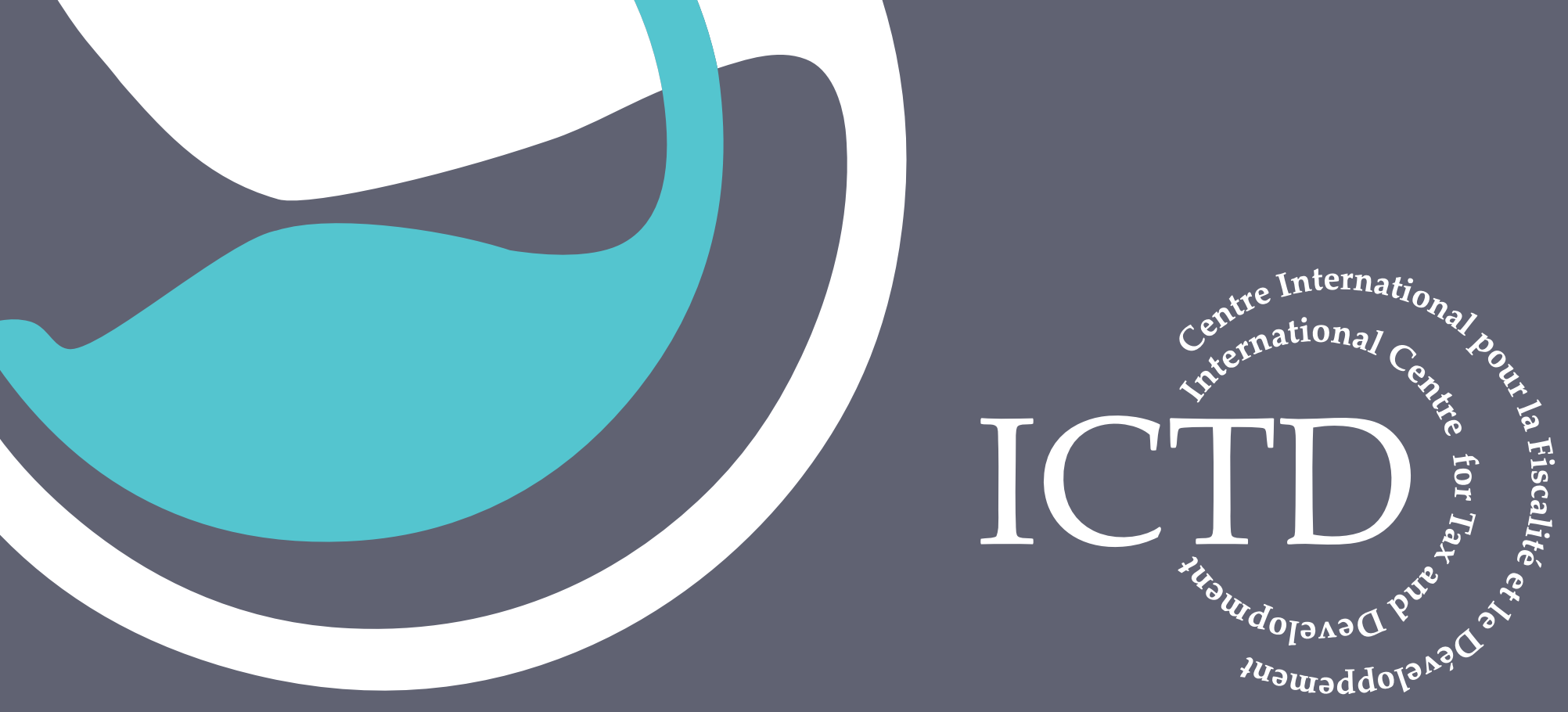

Working Paper 67

\title{
Cross-Border Trade, Insecurity and the Role of Customs: Some Lessons from Six Field Studies in (Post-)Conflict Regions
}

Thomas Cantens and Gaël Raballand August 2017 
ICTD Working Paper 67

Cross-Border Trade, Insecurity and the Role of Customs: Some Lessons from Six Field Studies in (Post-)Conflict Regions

Thomas Cantens and Gaël Raballand 
Cross-Border Trade, Insecurity and the Role of Customs: Some Lessons from Six Field Studies in (Post-)Conflict Regions Thomas Cantens and Gaël Raballand

ICTD Working Paper 67

First published by the Institute of Development Studies in August 2017

(c) Institute of Development Studies 2017

ISBN: 978-1-78118-382-3

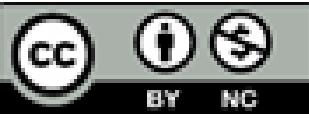

This is an Open Access paper distributed under the terms of the Creative Commons Attribution Non Commercial 4.0

International license, which permits downloading and sharing provided the original authors and source are credited - but the work is not used for commercial purposes. http://creativecommons.org/licenses/by-nc/4.0/legalcode

\section{Available from:}

The International Centre for Tax and Development at the Institute of Development Studies, Brighton BN1 9RE, UK

Tel: +44 (0) 1273606261

Email: info@ictd.ac.uk

Web: www.ictd/en/publications

IDS is a charitable company limited by guarantee and registered in England

Charity Registration Number 306371

Charitable Company Number 877338 


\section{Cross-Border Trade, Insecurity and the Role of Customs: Some Lessons from Six Field Studies in (Post-)Conflict Regions}

Thomas Cantens and Gaël Raballand

\section{Summary}

Africa, and especially the Sahel, has experienced frequent recurrences of armed conflicts and terrorist acts in the last decade. This paper is based on six field studies, in Chad, Mali, Sudan, Tunisia, Libya and the Central African Republic. It reflects on the governance of trade in border regions during a (post-)conflict situation, exploring the practices and strategies of customs officials operating at insecure borders. It demonstrates the unintended consequences of security policies - especially on trade, and consequently on revenue generation. It further shows how customs administrations de facto leave it to customs officers on the ground and importers to agree on an acceptable tax burden to prevent smuggling and a new upsurge in violence to a certain extent. Idiosyncratic and pragmatic approaches by customs seem to play a major role at the local level.

Keywords: customs; conflict; Africa; taxation; trade.

Thomas Cantens is a researcher at the World Customs Organization (Brussels) and associate lecturer at Clermont School of Economics.

Gaël Raballand is a leading public sector specialist, currently based in Tanzania. 


\section{Contents}

Summary 3

Acknowledgements

Introduction 6

$1 \quad$ Cross-border trade and customs in insecure areas $\quad 7$

$2 \quad$ Brief presentation of case studies 9

$3 \quad$ The impact of violence on trade routes 12

4 The response of customs to insecurity: an uncharacteristic yet balanced approach

4.1 Cooperation between border agencies 14

$\begin{array}{ll}\text { 4.2 The local importance of customs } & 15\end{array}$

4.3 Customs outposts as service providers and intelligence-gathering agencies 16

$\begin{array}{ll}\text { 4.4 Customs officers as local facilitators } & 17\end{array}$

4.5 A conflict between the autonomy of officials and the law?

4.6 A conflict between local and national taxation? 18

5 Conclusions and areas for further research to improve governance and taxation at borders $\quad 18$

$\begin{array}{ll}\text { Appendix } & 20\end{array}$

$\begin{array}{ll}\text { References } & 23\end{array}$

Tables

Table 1 Specificities of customs' actions, trade practices and insecurity from a customs perspective 


\section{Acknowledgements}

The authors wish to thank the participants of the BRIT 2016 Conference in Hamburg, HM Revenue and Customs and the Korea Customs Service for their support, as well as the customs administrations of Chad, Libya, Tunisia, Sudan, Mali and the Central African Republic. 


\section{Introduction}

This reflection is located at the intersection of two questions related to development that are usually treated separately. On the one hand, development and security form a nexus that has been widely explored by researchers for more than 20 years. On the other hand, more recently development and taxation have been interconnected. There is a strong emphasis in Africa on the need to collect more revenue to invest sustainably in poverty reduction. ${ }^{1}$

Despite ambitious targets (an average increase in the tax/GDP ratio of 4 percentage points), results have been rather disappointing for possibly two main reasons: (i) instability and insecurity have spread all over Africa, impeding tax collection; (ii) a top-down approach of reforms that do not take into account the need for staff incentives, and therefore may lead to limited results.

Trade taxes continue to account for between 30 and 50 per cent of total state revenue in Africa, making the role of customs critical for security, and revenue collection. Usually the focus is on a top-down approach to customs reform, considering a fragile environment an opportunity to start with a blank page for setting up a new institution. There is little literature on security, customs and trade; observations made in the field in these remote and conflictprone regions are even scarcer.

As will be discussed in the following section, customs officers operating at borders, as a part of the state, are invisible. Either a reflection is policy-oriented - conducted at state-level, linking instability and state-building through the relations between taxation, revenue collection and security (and sometimes the role of foreign aid in this context); or more sociological, aiming to describe the reality of governance at the border, to showcase 'hybrid' governance from the end-user perspective in case studies of specific insecure borderlands.

The main added value of this paper is that it present facts on revenue collection in conflictprone regions in Africa, and paves the way for discussion on (in)security, cross-border trade and the role of customs. This paper is a preliminary reflection, drawing lessons from six field missions conducted in fragile border regions - in northern Mali, at Chad's border on Lake Chad, at the Tunisia-Libya border from both Tunisian and Libyan sides, at Sudan's border with Chad in West Darfur, and in the northern borderlands of the Central African Republic neighbouring Chad and Cameroon (see maps in Appendix). Despite the situation differing from one country to another, common questions emerge on how to restore the authority of the state in areas of insecurity, and on the role to be played by state administrations particularly customs in this context. This paper is part of an ongoing research project on the role and practices of customs in conflict-prone regions, because customs is a state institution, combining coercion of and bargaining with economic actors. The paper does not address the question of how to restore a fully functioning customs administration in conflictprone regions, but how the security, economic and institutional environments affect customs revenue collection across the continent in six bordering regions at the time when pressure is mounting for customs to collect more revenue (even in these environments).

Given the risks attached to these environments and the difficulty of access to the field, a basic methodology was adopted as a first step. The choice of areas for fieldwork was opportunistic, based on safety and the importance of trade flows, because it is difficult to make observations on the ground in unstable regions. The current sample of border regions covers some of the major trade routes affected by security crisis in Northern Africa, Sahel and Central Africa. 
In terms of methodology, fieldwork was conducted with the support of national customs without this it would have been impossible to travel in those regions. However, anonymous interviews and formal meetings were conducted between July 2015 and January 2017 with traders, smugglers, transporters, police and army forces, state representatives, and militants in some cases.

The key messages of this paper are as follows:

- Customs administrations are flexible in conflict-prone borderlands, and tailor the fiscal burden to make it acceptable to local economic operators. The acceptability of taxation levels is to some extent negotiated with importers, to avoid or contain smuggling and boost local economic activity.

- Trade activities are resilient. In most cases trade still flows across conflict-prone territories despite violence. This means that traders pay a given price for security, or conclude alliances with violent groups. In cases where state actors have been replaced by non-state actors, the latter still ensure that crossings of goods generate resources through an informal type of taxation. Trade resilience can be explained by the fact that, irrespective of whether the actors are rebels/militias or state institutions, armed groups always need supplies. However, and possibly even more significantly, trade is resilient because all the armed groups want it to be resilient: controlling trade and ensuring that trade flows remain effective is a sign of governance capacity (and revenue) for those who aim to rule a territory.

- The local importance of customs in insecure areas is due to that administration's position on trade flows, and its role in supplying cash for other state actors and local authorities. Customs is usually the most important state institution dealing with traders and middlemen, such as brokers and hauliers. Middlemen develop a relationship with and negotiate with customs. This is important in cases where the state's presence is restored at fragile borders.

- Finally, traders may finance violent activities. Terrorist groups may also pay traders for intelligence to enable them to slip across borders. There appear to have been cases in northern Nigeria where Boko Haram paid traders to become informants. The same phenomenon was reported by Timbuktu residents in Mali.

This paper is set out as follows. Section 1 proposes a general review of the literature on cross-border trade, and the role of the state in insecure borderlands. Section 2 summarises the trade and security environment of customs administration in each area of fieldwork. It aims to highlight the main differences between customs administrations. The third section describes the impact of security on cross-border trade in the selected regions. It also shows how the traditional security response may have some unintended consequences that are detrimental to rebuilding the state in border regions. Section 4 presents some observations on customs practices developed in the field to accommodate conflict/post-conflict situations. The final section provides a conclusion and some areas for further research.

\section{Cross-border trade and customs in insecure}

\section{areas}

The relationship between the state, fiscal administrations, security and cross-border trade is analysed through three main approaches.

The first approach involves the general context of customs reforms. The weakness of border enforcement has been identified as one of the main causes for informal cross-border trade 
(Golub 2015). Informal trade is considered to occur in the margins, and to be something that needs to be reduced as much as possible for two main reasons: causing losses in revenue collection, and, more generally, as being some kind of challenge to state authority (Cantens et al. 2015). However, in developing countries informal businesses account for up to half the economic activity (La Porta and Shleifer 2014). Amin and Hoppe (2013), Ayadi et al. (2014), Brenton et al. (2014) and Bensassi et al. (forthcoming) demonstrated that informal crossborder trade in the Cameroon-Nigeria border, Tunisia-Libya border and East Africa is the most important income-generating activity, and consequently has a major impact on poverty reduction despite the fact that losses to the Treasury may be significant. ${ }^{2}$

A second approach is more sociological, based on what end-users experience at the border - concluding alliances, or negotiating with state and non-state actors regarding the governance of borders. Anthropological and geographical approaches highlight the network effects of informal trade (Walther 2009, 2015), and the hybrid model of governance that informal cross-border trade creates (Titeca and Flynn 2014). The second approach shows how informal cross-border trade is tolerated by national and local authorities to ensure income generation for the local population. It further demonstrates how informal cross-border trade is a local response to distrust of the national authorities. In some cases the state may be perceived as illegitimate: informal cross-border trade, by undermining the state, is therefore a way to fight it. This study also shows how taxation levels are negotiated locally (Roitman 2007; Titeca and Flynn 2014; Reyntjens 2014). It goes on to illustrate how informal trade is a means of surviving, and how non-state institutions can emerge in the regulation of the border (Raeymaekers 2010). It also highlights possible collusion between some state institutions and some large informal traders. However, this literature does not examine the role of customs in detail as it is considered a state institution, nor the role of fiscal administrations within a context of organised violence.

A third approach directly addresses the work and practice of civil servants in general, and customs officials in particular. This literature is mainly focused on points of entry like ports and airports, either to analyse the real governance of international trade (Chalfin 2004, 2008, 2010; Cantens 2012, 2013, 2015), or to address the question of corruption (Cantens et al. 2010; Raballand and Rajaram 2013) and discuss anti-corruption policies in customs (Cantens and Polner 2016). However, the role of customs officers in insecure areas has never been addressed.

To some extent the literature dealing with borders, taxation and organised violence often adopts two contrasting perspectives, either 'from below' (giving more prominence to the experience of end-users (traders, transporters)), or 'from above' (from a state perspective). Security in developing countries has been widely addressed from a state-centric perspective, as shown by an exhaustive review of literature on 'hybrid security arrangements in fragile and conflict-affected spaces' by Luckham and Kirk (2012). Even if the state is represented as a body affected by violence and corruption, it is still represented as a body - civil servants are absent or left in the margins in these two poles of literature. Two exceptions should be noted, beyond African borders. Firstly, Klem (2012) gives an account of the role and practices of civil servants in a crisis zone in Sri Lanka. Sugget (2005), an Australian customs officer, describes his experience as a customs expert participating in state-building in East Timor in 1999.

The academic literature agrees on the way state and non-state actors participate in this hybrid or negotiated governance of cross-border trade, as the main economic resource and the most easily taxable in the context of insecure areas. The interest in this hybridity in times of conflict has been driven recently by the influence of Tilly on academics, regarding the formation of the state through war, gaining prominence on the Weberian model (Meagher

2 For example, losses in Tunisia are estimated to be a quarter of the revenue collected by customs (Ayadi et al. 2014). 
2012). However, focusing on the loss of power and authority by state services, and the hybrid/negotiated governance of the border, has sometimes blurred the fact that within any negotiation there are at least two parties. The perspective of civil servants - in this case customs officers operating at borders in insecure areas - seems to be underestimated. It is still important to explore their practices and strategies, as they are a concrete part of the governance de facto adopted in insecure areas.

\section{Brief presentation of case studies}

The situation of customs administrations operating at borders differs from one country to another, but at least two common points have been observed that contribute to the general description of border trade and management in the six selected regions.

In all cases, smugglers of consumer goods - whose activities constitute the core interest of our study - are mainly focused on specific goods for home consumption (textiles, flour, vegetable oil, coffee, tea, agricultural goods and home appliances); fuel and cigarettes are commonly the most heavily-taxed goods smuggled by these traders. It has not been observed or reported that these smugglers of consumer goods, the majority of informal traders in these areas, smuggle high-value goods like gold, or goods subject to special restrictions like weapons or drugs.

Smugglers may have means of transport (donkeys, pick-up vehicles) that allow them some flexibility to cross borders and bypass the control of customs. However, in terms of revenue collection a general customs strategy is to be located at trade hubs, the border cities to which commodity flows converge before being unloaded and dispatched to surrounding areas or sold in markets to urban and rural populations. Insecurity and army patrols in no-go zones are the second reason forcing smugglers not to move too far away from the usual and most frequented roads.

Table 1 summarises the specificities of customs' actions, trade practices ${ }^{3}$ and insecurity from a customs perspective, providing a broad overview of the six case studies. 
Table 1 Specificities of customs' actions, trade practices and insecurity from a customs perspective

\begin{tabular}{|c|c|c|c|}
\hline & Customs administration & Trade practices & Insecurity issues \\
\hline $\begin{array}{l}\text { Tunisia } \\
\text { Ras-Jedir - } \\
\text { border with } \\
\text { Libya }\end{array}$ & $\begin{array}{l}\text { At the customs bureau located on the } \\
\text { border at Ras-Jedir, in charge of } \\
\text { controlling passengers and cargo, } \\
\text { customs controls the closure of } \\
\text { armoured gates on the road crossing } \\
\text { the border. } \\
\text { Customs outposts are located along } \\
\text { the border with Libya, from which } \\
\text { customs can organise patrols. }\end{array}$ & $\begin{array}{l}\text { Trucks, individual vehicles } \\
\text { and individuals are used to } \\
\text { carry commodities. } \\
\text { Pick-up vehicles are used to } \\
\text { smuggle goods in the desert. } \\
\text { Currency exchange is highly } \\
\text { developed in the border city } \\
\text { of Ben Guerdane. }\end{array}$ & $\begin{array}{l}\text { The main threat is terrorist groups } \\
\text { that come from Libya to attack } \\
\text { Tunisian cities (like Ben } \\
\text { Guerdane in 2016), and people } \\
\text { wanted for terrorist activities who } \\
\text { escape from Tunisia and go to } \\
\text { Libya. } \\
\text { A second specific insecurity } \\
\text { concern is linked to smuggling } \\
\text { activities: the population of Ben } \\
\text { Guerdane is highly dependent on } \\
\text { cross-border trade activities. Any } \\
\text { closure of the border or changes } \\
\text { in Libyan trade control policy } \\
\text { cause popular unrest on the } \\
\text { Tunisian side in the city of Ben } \\
\text { Guerdane. }\end{array}$ \\
\hline $\begin{array}{l}\text { Libya } \\
\text { Ras-Jedir - } \\
\text { border with } \\
\text { Tunisia }\end{array}$ & $\begin{array}{l}\text { Despite the current Libyan state } \\
\text { being under reconstruction, the } \\
\text { customs administration benefits from } \\
\text { relative institutional stability. } \\
\text { At the border with Tunisia, Libyan } \\
\text { customs is represented by units with } \\
\text { some personnel who are native of } \\
\text { the area. Libyan customs has } \\
\text { launched an important recruitment } \\
\text { campaign among members of armed } \\
\text { groups. }\end{array}$ & $\begin{array}{l}\text { Cross-border trade activities } \\
\text { are similar to those in Tunisia. } \\
\text { However, there is no border } \\
\text { city acting as a trade hub, so } \\
\text { cargo spreads all over the } \\
\text { territory and alongside the } \\
\text { Tripolitan Road to Tripoli. }\end{array}$ & $\begin{array}{l}\text { Security concerns are related to } \\
\text { terrorism and the current } \\
\text { fragmentation of Libyan territory. } \\
\text { Access to certain parts of territory } \\
\text { are still ruled by militias (katibas); } \\
\text { this is still a potential obstacle for } \\
\text { the full deployment of a national } \\
\text { administration. }\end{array}$ \\
\hline $\begin{array}{l}\text { Mali }^{\mathbf{4}} \\
\text { Timbuktu and } \\
\text { Gao - } \\
\text { Northern Mali }\end{array}$ & $\begin{array}{l}\text { In } 2012 \text { customs administration, like } \\
\text { other state services including the } \\
\text { army, left the area ruled by rebels } \\
\text { and jihadist groups. In } 2015 \text { the } \\
\text { customs administration progressively } \\
\text { sent staff to Timbuktu and Gao. } \\
\text { However, customs administration is } \\
\text { not present at the border with } \\
\text { Mauritania and Algeria. } \\
\text { The main objective of customs is to } \\
\text { contain informal trade, particularly } \\
\text { trade flows coming from Algeria - } \\
\text { where some consumer goods benefit } \\
\text { from state subsidies. The concern is } \\
\text { that necessities that are smuggled } \\
\text { into northern trade hubs (Timbuktu, } \\
\text { Gao) are resold in southern markets, } \\
\text { where imported commodities from } \\
\text { Sénégal and Côte d'Ivoire are } \\
\text { submitted to higher legal taxation. }\end{array}$ & $\begin{array}{l}\text { Mali is a landlocked country. } \\
\text { Two main points of entry - } \\
\text { Kayes and Sikasso-Zegoua in } \\
\text { the southern part of the } \\
\text { country - process most trade } \\
\text { flows from Senegal and Côte } \\
\text { d'Ivoire. } \\
\text { Commodities enter northern } \\
\text { Mali through three routes: } \\
\text { from Mauritania to Timbuktu, } \\
\text { from Algeria (Tamanrasset) } \\
\text { through Kidal, and } \\
\text { from Algeria and other } \\
\text { northern African countries } \\
\text { (Libya, Egypt) through Niger } \\
\text { and Menaka. } \\
\text { Cities like Timbuktu and Gao } \\
\text { in north Mali are historical } \\
\text { trade cities, where traders' } \\
\text { communities are important } \\
\text { and markets attract nomadic } \\
\text { and rural populations. } \\
\text { Trucks are used to trade with } \\
\text { Algeria; pick-ups are more } \\
\text { used for trade between } \\
\text { Timbuktu and Mauritania. }\end{array}$ & $\begin{array}{l}\text { The level of insecurity is still high } \\
\text { in Northern Mali due to the } \\
\text { presence of armed groups whose } \\
\text { weapons can be very } \\
\text { sophisticated; this is an obstacle } \\
\text { to full deployment of customs } \\
\text { units. }\end{array}$ \\
\hline $\begin{array}{l}\text { Chad } \\
\text { Bol - } \\
\text { Lake Chad }\end{array}$ & $\begin{array}{l}\text { Customs administration is under the } \\
\text { authority of the Ministry of Finance. } \\
\text { However, many senior customs } \\
\text { officers are former fighters. } \\
\text { Contrary to some other customs } \\
\text { administrations in the Lake Chad }\end{array}$ & $\begin{array}{l}\text { The Chadian government } \\
\text { implemented a state of } \\
\text { emergency in the Lake Chad } \\
\text { region, imposing curfews, } \\
\text { closing the border on the } \\
\text { Lake itself, prohibiting the use } \\
\text { of certain means of transport }\end{array}$ & $\begin{array}{l}\text { The major threat is Boko Haram. } \\
\text { The level of insecurity is } \\
\text { important, but has decreased } \\
\text { since } 2016 \text {. }\end{array}$ \\
\hline
\end{tabular}

\footnotetext{
$4 \quad$ See Cantens and Raballand (2016).
} 


\begin{tabular}{|c|c|c|c|}
\hline & $\begin{array}{l}\text { Basin, Chadian customs remained in } \\
\text { their offices despite the rise of Boko } \\
\text { Haram in } 2011 \text { - particularly in Bol on } \\
\text { the banks of Lake Chad, despite } \\
\text { multiple incursions of armed groups } \\
\text { in the area. }\end{array}$ & $\begin{array}{l}\text { (like large boats that used to } \\
\text { transport commodities from } \\
\text { Nigeria through the Lake). } \\
\text { Cameroon and Nigeria closed } \\
\text { the usual trade road crossing } \\
\text { the northern parts of these } \\
\text { countries along which } \\
\text { Nigerian commodities } \\
\text { transited. Consequently, } \\
\text { traders use small trucks and } \\
\text { new routes going through } \\
\text { Niger. } \\
\text { Traders in localities like Bol } \\
\text { are organised through a } \\
\text { group whose members go to } \\
\text { Nigerian cities, particularly } \\
\text { Lagos, to buy goods on } \\
\text { behalf of the others. }\end{array}$ & \\
\hline $\begin{array}{l}\text { Central } \\
\text { African } \\
\text { Republic } \\
\text { (CAR) } \\
\text { Northern } \\
\text { borders with } \\
\text { Chad and } \\
\text { Cameroon }\end{array}$ & $\begin{array}{l}\text { From a customs perspective, CAR } \\
\text { territory is divided into three parts. } \\
\text { State services are present along the } \\
\text { road between the border with } \\
\text { Cameroon (Beloko) and the capital } \\
\text { Bangui. This road is the major supply } \\
\text { route for the capital, where } 25 \% \text { of } \\
\text { the national population live. } \\
\text { Commodities are conveyed through } \\
\text { the transit corridor from Douala port } \\
\text { in Cameroon to the border post of } \\
\text { Beloko, then escorted by UN military } \\
\text { units accompanied by customs units. } \\
\text { Customs and state services are not } \\
\text { deployed in the eastern and northern } \\
\text { part of the territory, which is ruled by } \\
\text { militias (ex-Seleka). } \\
\text { The northern and western part of the } \\
\text { territory is mainly ruled by militias } \\
\text { (anti-Balaka), but there is a customs } \\
\text { bureau in the town of Bang at the } \\
\text { extreme northern border with Chad } \\
\text { and Cameroon. This bureau has } \\
\text { been attacked several times. }\end{array}$ & $\begin{array}{l}\text { In the western part of the } \\
\text { countries, apart from the } \\
\text { Douala-Beloko-Bangui area } \\
\text { that provides the major share } \\
\text { of trade, traders circulate } \\
\text { from one border to the } \\
\text { hinterland depending on trade } \\
\text { opportunities offered in } \\
\text { Cameroon market cities } \\
\text { nearby the border. }\end{array}$ & $\begin{array}{l}\text { Insecurity is widespread and } \\
\text { villagers and cities are regularly } \\
\text { raided by armed groups; this } \\
\text { leads to local militias, who can } \\
\text { become a threat to other villages } \\
\text { or localities. } \\
\text { A particularity of this situation is } \\
\text { the presence of the UN } \\
\text { peacekeeping mission, whose } \\
\text { Blue Helmet contingents are } \\
\text { located in major cities along the } \\
\text { trade roads. The CAR army is not } \\
\text { deployed in the field, and CAR is } \\
\text { under weapons embargo. }\end{array}$ \\
\hline $\begin{array}{l}\text { Sudan } \\
\text { West Darfur, } \\
\text { border with } \\
\text { Chad }\end{array}$ & $\begin{array}{l}\text { The major organisational specificity } \\
\text { of Sudanese customs is that they are } \\
\text { part of the Ministry of Interior, which } \\
\text { simplifies the lead of border } \\
\text { agencies. } \\
\text { Customs operate in the customs } \\
\text { bureau of El Geneina, as well as in } \\
\text { an outpost in a village located } \\
\text { between El Geneina and the border } \\
\text { with Sudan. }\end{array}$ & $\begin{array}{l}\text { Traders use trucks and pick- } \\
\text { ups. Their trade routes } \\
\text { extend from Port Sudan to } \\
\text { northern Nigeria, where some } \\
\text { traders barter (Nigerian } \\
\text { commodities for leather). } \\
\\
\text { Some border villages are } \\
\text { areas of small-scale } \\
\text { smuggling: people use small } \\
\text { vehicles or donkeys to ship } \\
\text { commodities between Chad } \\
\text { and Sudan. }\end{array}$ & $\begin{array}{l}\text { Insecurity has been addressed } \\
\text { through different ways. Former } \\
\text { militants have been encouraged } \\
\text { to convert their vehicles into } \\
\text { means of transport for goods and } \\
\text { people. An agreement between } \\
\text { Sudan and Chad set up a joint } \\
\text { force that has settled camps to } \\
\text { protect the border town of El } \\
\text { Geneina (Sudan) and the road to } \\
\text { the border. }\end{array}$ \\
\hline
\end{tabular}




\section{The impact of violence on trade routes}

Violence may or may not affect trade routes (and reduce supplies due to official border closures). ${ }^{5}$ However, the major driver of change may be not insecurity itself, but rather the state's response to it.

States adopt three kinds of responses that can be observed in the field. The first response is a non-response: security forces and administrations are no longer present in the borderlands. Security can be ensured by foreign armies (United Nations peacekeeping operations, or partner countries' armies - such as France in Mali), or militias - as is the case in the Central African Republic. Where security is ensured by local militias, these militias can be composed of former civilians who 'helped' security forces formerly present at roadblocks or in villages by accomplishing small tasks officers did not do (opening the barrier, making registrations, collecting informal fees). However, according to some interviews in the Central African borderlands, these militias do not apply the same kind of informal taxation to all traders. They tend to favour traders who are, for instance, from the same religion, and put a lot of pressure on others (detaining vehicles and drivers, increasing fees).

The consequence of this non-response by the state can be changes in the structure of the trading community, which is reshuffled according to violence in society and the domination of new social groups: some traders are obliged to flee the area and are replaced by those who are close to the ruling groups (case of Central African Republic). In this case, the trade routes do not change. A similar observation regarding the permanence of trade routes, for different reasons, has been made in northern Mali. After Algeria closed its border with Mali in 2013 the volume of trade between Algeria and Mali decreased by two-thirds, but the closure did not stopped smuggling (Bensassi et al. forthcoming). The trade roads crossing the desert did not change, probably due to the absence of the Malian army and security forces in these areas. Trade routes did not change in the borderlands between Mauritania and Mali, either. According to various interviews and field observations, Timbuktu, for instance, is still strongly connected to the borderlands with Mauritania. Markets in Mauritania, a few kilometers from the border with Mali, supply the Timbuktu area. Violence did not dramatically modify the trade routes when the state was absent. ${ }^{6}$

The second kind of state response to insecurity is the closure of the border and a strong state presence to implement the closure. There have been some major changes in trade routes in Chad, as the government has banned large vessels from using Lake Chad. The main roads between Lagos and N'djamena, by Lake Chad or by Fotokol and Kousseri in Cameroon, have been closed and declared military zones. Trade routes have had to be changed as a result, for example through Niger. These changes had two major consequences.

Firstly, changes to trade routes have several major consequences at the local and national levels, one of which is a rise in the price of goods. For instance, large vessels on Lake Chad could transport the equivalent of three truckloads. Their ban automatically increased transport prices due to a change in means of transport. According to Bol residents, the price of basic goods has increased by 30 per cent since the ban came into force. ${ }^{7}$ New trade routes create new opportunities for states rather than for traders. For example, Niger has benefited from increased transit flows to Chad from Nigerian ports; Nigerien customs

\footnotetext{
$5 \quad$ Trade routes are a more theoretical concept, given that drivers use GPS devices in conflict-prone/volatile environments and continuously change their routes (see Bensassi et al. forthcoming).

$6 \quad$ Armed groups require all manner of supplies (including petrol for vehicles). They consequently control checkpoints or levy some taxes, but do not stop trade flows. There are also anecdotes about informal taxation of drug flows (with tolls paid to tribes to ensure safe passage).

The residents who were interviewed had been inhabitants of Bol since 2010 .
} 
manages the new transit flows and collects new transit fees stemming from increased transit flows to Chad, and goods are also taxed by Chadian customs. Niger and Chad customs signed an agreement to avoid this double taxation by the end of 2016.

Secondly, when trade routes are reshuffled due to violence, some cities or regions neighbouring the fragile area may compete to attract new trade flows. This competition can exist between state institutions, armed groups and even cities that find new opportunities to be connected to border economies. It can be based on the price of providing security and result in competition in the cost of securing transport (formal and informal) and customs duties. But, the most important competition is between border towns to attract trade crossing conflict zones: this can have an impact on state revenue at national level. This has previously been described between customs bureaux (Cantens 2013), but it becomes fiercer in the case of regions neighbouring conflict zones. It can be driven by local authorities using customs offices as allies, or by customs offices themselves. The range of 'facilitation measures' can be wide: from lowering fiscal pressure (for instance, by carrying out an overall valuation of loads, and setting a global tax per lorry), to providing security escorts for a fee.

Such competition has been observed in many countries. It can have positive consequences: forcing local security services to coordinate more fully to decrease informal and formal fees collected at roadblocks or for escorts; or forcing major offices to tailor their services and modernise their procedures when faced with pressure from smaller offices that want to attract more flows of goods. Nonetheless, it can also have negative effects: locally, an office can decrease fiscal pressure and then increase its revenue collection; the competition will force other offices to do the same, thus reducing overall tax collection. In all areas where borders have been closed and trade routes changed, local representatives of border regions, states and cities and heads of customs have to balance between: (i) securing local income for their region or city through taxation; (ii) not being too compliant with legislation and procedures with the main security actors in the field - customs, army and policy officials at roadblocks who may collect some informal fees; and (iii) maintaining an acceptable (informal and formal) tax pressure that does not discourage traders from going to neighbouring regions or cities to clear their goods.

The third kind of local state response regarding the openness of the border is to 'reduce' the border. In some regions, like at the Tunisia-Libya border, Tunisian authorities adopted some restricted access to border areas, keeping few border posts open and delineating military zones where traffic is prohibited. The main rationale for this measure is to reduce smuggling and illegal entry into the country, not to deploy additional civil service resources in insecure areas and to keep the border open. The trade routes have not changed much. The adoption of this strategy seems to have been fruitful in Tunisia. From interviews with smugglers and customs officials, it seems that smugglers make a clear distinction between state services that fight against terrorism and religious armed groups operating in the borderlands whose ideology is supported by smugglers. This was evidenced in March 2016, when a group of Islamic State militants tried to take the Tunisian border city of Ben Guerdane, and were not supported by the population. Keeping the border open is crucial in areas where the border is an important economic resource, as this policy enables customs officers to maintain a good relationship with all kinds of local traders. According to some smugglers interviewed in Tunisia, their primary intellectual opposition against extreme religious ideologies is an important factor. The state response in such an environment mainly consists, therefore, in keeping cross-border traders as allies.

Many security solutions applied at fragile borders have unintended consequences. Security solutions usually do not make any distinction between the type of flows crossing the border (legal or illegal trade and migration flows). In many cases, state security forces assume there are connections between all flows (terrorists, smugglers, drug traffickers, hauliers, migrants, 
etc.) and apply the same level of force to all flows. ${ }^{8}$ For some policymakers or local civil servants operating at fragile borders there may be a link between smuggling and terrorism, based on, for instance, the use of the same means of transport or the same empirical knowledge of field conditions, or a general statement on deterministic linkages between all illegal activities.

However, there is often no clear evidence of structural links between, for instance, terrorists and smugglers, or jihadists and drug traffickers (Lacher 2012). The indiscriminate use of force may worsen the relationship between local communities living in borderlands and civil servants or soldiers, who require the support of these local communities to adapt the rules to local circumstances, collect intelligence and help enforce security measures.

As described before, some security solutions may be extreme - such as closing the border, or closing markets in a border city that is a trade hub. State authorities justify such measures to protect civil servants at the border against suicide attacks - a trade route is closed and border controls simplified to break the potential financial links between certain traders and terrorists; all attempts to cross the border are considered a potential terrorist act.

Smuggling can persist and some smugglers may be connected to armed groups even in cases where there is no longer any formal trade activity. The escalation of state violence in borderlands increases the level of risk for smugglers, who may opt to smuggle high-value goods such as weapons or drugs. The anticipated benefits of border closures in security terms may consequently not be as significant as hoped, and need to be carefully assessed. Moreover, border closures have a huge impact locally; they can contribute to a drastic reduction in the transport and trade sectors - these are the main areas of employment, and help to reduce poverty.

\section{The response of customs to insecurity: an uncharacteristic yet balanced approach}

Customs services are often envisaged solely as national administrations, yet they play an important role in wealth redistribution - especially in areas where revenue from cross-border trade is the main economic resource. The key questions challenging customs authorities are the following. What role could be played by customs and, more globally, the state to support simultaneous development of trade and revenue collection? What impact does violence have on trade activities, and what are the practical responses adopted by customs to ensure trade and resilience? What is the role of customs in the local security framework? What practices does customs adopt locally to restore the authority of the state, and what are the risks associated with these practices? This section shares some examples of local responses, and the principles guiding them.

\subsection{Cooperation between border agencies}

As a preliminary observation, it is worth clarifying the scale of cooperation between border agencies, both national and international. Different situations have been observed, all with their own advantages and disadvantages.

Proponents of this view include Michailof (2015). This view is shared by many policymakers and representatives of aid agencies, whereas research in this area is much more nuanced (Lacher 2012; Cantens and Raballand 2016). This was confirmed through interviews. 
The situation may differ between northern Mali and Chad: while Malian customs is limited to a symbolic presence in the main towns, Chadian customs still operates some customs offices on the frontline. However, a common feature of both countries is that the governor coordinates border agencies, and this coordination is implemented in practice by the army. Customs officers are sometimes embedded within army patrol units, enabling seizures to be made according to customs regulations, maintaining visible customs contact in the field, and giving customs officers the opportunity to patrol under reasonable security conditions.

The Sudanese case is unusual from the perspective of coordination of border management. Customs is part of the police force, under the authority of the Ministry of the Interior, and has the same equipment, uniforms and powers as the police (except for specific intervention groups). Sudanese customs has established close cooperation with other police services in charge of intelligence in economic affairs. Formal exchange of information has been established, particularly to monitor transit movements. However, the most important positive step is coordination with Chad, taking the form of an agreement recently signed between Chad and Sudan. Joint forces have been set up at entry points to El Geneina and on the road to Chad, with joint patrols operating in the area. All the actors have reported that this agreement has led to a positive dramatic change. According to the police chief responsible for police and customs forces in West Darfur, there has been a 'complete turnaround', proving that international cooperation can work to ensure security when it is concretely implemented in the field by joint forces.

Another type of cooperation deserving greater empirical exploration is the relationship between state services and traditional authorities (such as sultans in Sudan, heads of villages or tribes in Mali). The situation seems to differ from one country to another. In Sudan, the role of traditional authorities (like the sultans in El Geneina) appear to have diminished, based on interviews. This situation differs from other locations (such as Mali) where donors' approaches to peacebuilding have relied mainly on the role of traditional authorities in the absence of the state. In northern Mali local chiefs' authority within communities seems to have gradually declined; they are often considered to be an obstacle to development as their authority is based on traditional hierarchy. As a corollary, donors or state institutions run the risk of being perceived as allies of the ruling elite.

There is probably not any single model for border cooperation, but three main lessons can be drawn at this stage. Firstly, customs are not always important actors in the national security schemes, apart from in Tunisia and Sudan. This is despite the fact that customs, differently to other security forces, have both security and economic perspectives on the crisis, especially in borderlands where trade is one of the major economic activities. Secondly, the army may be an important actor in cooperation for border management. Usually, experts think of border cooperation in terms of civil or paramilitary services (such as customs, police, border guards, health and sanitary services). However, in insecure areas the army is often the main actor with the technical means to patrol the borderlands. Moreover, customs share this 'patrolling culture' with the army in borderlands - as opposed to the police, which are more focused on urban areas. Thirdly, cooperation with the local population should be conducted with caution: the role of traditional and religious authorities may not be as important as it seems, and economic elites like traders may provide more powerful support to state services.

\subsection{The local importance of customs}

Despite all policymakers and experts encouraging cooperation between governmental agencies, the presence of the state at fragile borders also results in power struggles among state services. Leadership may evolve quickly due to a range of parameters: reduced insecurity, differing balance of power and intelligence sources. 
Struggles between border control agencies have come to the fore in some countries, particularly between customs, army and police services, as they jostle to be physically present at 'point zero' of the border. ${ }^{9}$ The border agency that handles point zero may receive more equipment and resources from central government, especially to monitor the border and close it in an emergency. In one country, customs heads of office demonstrated their efficiency by showing that when posted to one point of entry after the army, customs officers increased the tonnage of seizures. As a result, the government changed the security framework, and gave customs the keys to the border by positioning it at point zero, granting it legal authority to close the border in an emergency - thus raising the profile of customs, locally, within the security forces. This is not necessarily a transposable model, as it depends on many factors that are not replicable in all countries. It does, nevertheless, show that there is no specific model for security policy in which customs would only be assigned a secondary role.

In other countries, customs experiences a strengthening of its powers when cash supply is restricted. The availability of cash is crucial for state services where banking is less developed for economic reasons (size of the market, high transaction costs) or insecurity (absence of bank branches), where wages or bonuses are paid to civil servants in cash, and where local service providers to state authorities are also paid in cash. The governor or local government rely on cash flows to exert their authority and ensure the functioning of their own services. In these environments, customs is one of the main cash providers. This is one of the reasons why local state authorities often ask to be supported in the field by a strong presence of customs teams.

\subsection{Customs outposts as service providers and intelligence-gathering agencies}

In addition to a main customs office located on the main road, some customs administrations have set up outposts. These customs outposts are usually established near informal trade routes or a village where people employ basic means of smuggling. The outposts are not far from small military camps to keep them safe, and they may play a part in state control policy set up by the government. Customs outposts are usually located between the border and border cities. ${ }^{10}$

Customs officials operating there tend to tolerate petty smuggling for various reasons sometimes due to corruption, but also in order to avoid the risk of riots or creating political instability by blindly applying the same tax burden to all. Importers are not allowed, by law, to clear their goods at outposts. Customs officers usually give a laissez-passer to cargo or vehicle owners, asking them to go to the main customs office to clear their goods.

In two countries there has also been an explicit policy to build customs posts near the border that would provide local people with services, such as telephone and electricity. This kind of policy used to exist during colonial times, when outposts were intended to attract nomadic people or travellers for control, taxation or intelligence purposes. This has produced results in one country, in particular. On one occasion customs officers operating at the outpost were informed that two terrorists were about to cross the border, and this led to their capture. It also shows that customs now considers its mission to be intelligence-gathering, rather than collecting revenue and punishing smugglers.

\footnotetext{
9 The administration at point zero is located at the geographical location of the border, and is the first to deal with flows of individuals and goods entering the territory.

In many developing and emerging countries there are 'border cities' that are not necessarily located at the border, but attract cross-border flows because they provide different services such as fuel, mechanical repairs and markets.
} 


\subsection{Customs officers as local facilitators}

At all fragile borders, when the border is open customs plays a role as interface-negotiatorpeacemaker between traders/hauliers and the national or foreign public authorities. This role is crucial, because it grants legitimacy to the state after an outbreak of conflict. During a group interview one broker said that 'customs cooperates' - meaning, in that context, that other authorities do not, particularly local authorities.

In almost all fragile borderlands, customs officers benefit from an informal agreement with headquarters granting them flexibility to make the fiscal burden on traders acceptable. This forms part of the trade facilitation role conducted by customs and is developed locally and empirically, even though more research is needed to show its relevance and highlight the associated risks - particularly corruption and tax evasion. Customs officers and importers meet regularly to agree on the acceptable tax burden, in order to avoid smuggling and corruption.

A final observation on customs' role as an intermediary is linked to the relationship between traders and foreign administrations. For instance, Sudanese traders have an accurate grasp of the level of taxation that can be leveraged by the Sudanese government on Chadian traders, and the 'unfairness' prompted by the asymmetry of taxation on each side of the border. A Sudanese trader complained that Chad levies taxes on goods in transit without issuing any receipt, and suggested that Sudan also levy taxes on transit goods. The role of customs as an intermediary between Sudanese traders and foreign authorities was particularly striking during a meeting organised in Adré (Chad). The meeting brought together two delegations from Chad and Sudan, both comprising customs officials and traders. The traders - whether Chadian or Sudanese - were quick to take the floor and describe their difficulties to the authorities. Some public service representatives also presented cases of traders being blocked by customs on the other side of the border. The fact that traders were accompanied by customs officials gave them symbolic power to negotiate and publicly air their grievances. This kind of meeting is remarkable in terms of the transparency it brings to trade issues, and can be a good way of easing tensions in areas affected by violence.

\subsection{A conflict between the autonomy of officials and the law?}

Negotiating local tax collection by national administrations needs to include a strong reflection on corruption. Although negotiating import values locally may not comply with international standards, it can prove efficient in a context where there is limited documentation and where trade is the main local economic resource. It could be argued that bargaining could encourage corruption, since the tax burden is negotiated directly between local actors who are in daily contact. On the other hand, it could also be a way to reduce corruption by making customs clearance processes transparently uniform (goods are usually cleared by the lorry- or car-load -sometimes based on the type of goods).

If some sort of autonomy should be given, locally, to officers to provide adaptive responses to insecurity through taxation, the potential risks of such autonomy should be evaluated. Indeed, as has been observed in Northern Mali (Cantens et Raballand 2016), the defiance of populations against the state is high due to the corruption, and sometimes violence, of state services. An economic operator in the northern region of Mali described himself as a 'republican trader', complying with the rules, and he clearly described why corruption creates inequality, difficulties for newcomers to access the border economies, and reproduction of elites. The bargaining process should not, therefore, create the conditions to restore a corrupt state, which would guarantee that the same violent claims would emerge sooner or later. Some solutions may exist that contradict current policies, particularly regarding the deployment of material resources in fragile environments. The central administrations are very often reluctant to send resources to fragile areas, arguing that these resources would be 
destroyed or stolen, providing more resources to armed groups. This point is very often an internal source of conflict between local officials serving in fragile borderlands and headquarters.

In many countries, autonomy that is granted locally to officers is evaluated through two criteria: achievement of revenue targets (common to all customs bureaux in developing countries and encouraging competition among them (Cantens 2012)), and, more specifically, the fact that economic operators - who can be former militants of armed groups - do not complain and themselves engage in violence.

\subsection{A conflict between local and national taxation?}

The practices described above may be valuable in restoring a peaceful relationship between state services and economic operators. However, they may also raise an apparent conflict between local and national taxation. Customs is a national administration, but we have seen that its local representatives operate with pragmatism, enjoying a degree of informal or formal flexibility granted by the central authority. But locally there are political authorities (municipality, local state in a federal state, governorates), local bureaucracies that have the power and capability to levy taxes (on transport, markets) that affect traders. If primacy is to be given to the local dimension in fragile borderlands, what should be the relationship between local and national taxation schemes? On the one hand, it can be argued that locally the geographical proximity between taxpayers and those who spend taxes (mayors, governors, local governments) encourages accountability and transparency. On the other hand, and employing the same proximity-based rationale, one could argue that closer and tighter connections between elite taxpayers (who are the main local contributors) and local political elites can also provide an opportunity for more patronage and corruption.

To some extent customs plays a political role by locally tailoring the tax burden in the interest of stability, and, in some cases, its procedures and outcomes (valuation, quantity assessments) are used as inputs for local tax assessments. In other cases, the local authority may even levy a new tax and ask customs to collect it. Some interviews with traders have shown that they tend to place greater trust in customs (as its procedures and assessments do not vary and customs cooperates) than in local authorities that have been described as more 'resourceful' in terms of tax pressure.

This potential conflict between local and national levels illustrates the importance of taxation in crisis resolution: taxation can play a role in building trust between people and local authorities. It is important to highlight this dimension in the nexus of security and development: the restoration of taxation is a strong political leverage to rebuild the relationship between people and authorities, and the local role of national administrations is crucial in this regard (Moore 2007).

\section{Conclusions and areas for further research to improve governance and taxation at borders}

This paper has attempted to present some observations from borders in conflict areas. There are some obvious limits to the observations, with no quantitative analysis. It shows just how idiosyncratic borderlands are, and how a military solution will not lead to development in those regions (Cantens et Raballand 2016). In this context, customs has a major role to play even though it needs to adapt to local situations and local rules. Customs can greatly contribute to a transitional state by providing an economic perspective to policymakers. The 
state's presence should balance economic activities, the rule of law and acceptance of the state by local people.

The concept of trade facilitation may take on a new meaning in fragile border regions: facilitating trade has a political dimension, enabling the state to restore its authority by creating equal conditions of access to trade in areas where the border is an economic resource for the local population, as opposed to armed groups whose policies and actions are based on discrimination and inequality.

In addition to these ideas, which need to be described with greater accuracy, some further questions remain.

The first question is about the circulation of cash and, more generally, currencies near borders (and beyond) - and money laundering. The latter connects fragile borderlands where profits are generated (due to smuggling and drug or weapons trafficking), and capital cities where the profits are invested. This situation creates a trade-off for the authorities, observed in some countries, between generally turning a blind eye to investigating money laundering, because the currency comes from a conflict-prone zone far from the capital and has been reinvested in the capital, and combating money laundering with the concomitant risk that profits are no longer invested in the country. In any event, currency movements related to informal financing (using, for example, hawala systems ${ }^{11}$ ) deserve more attention, to understand how they do or do not contribute to trade facilitation and their related risks.

The second question is the relationship between smuggling and terrorism. This link, often upheld by policymakers, is sometimes based on anecdotes of individuals being involved in both activities, and on a general assumption that terrorists and smugglers cross borders illegally, have the same means of transport (pick-up vehicles) and the same knowledge of the natural environment. There clearly are cases of smugglers who become involved in terrorist activities, though many questions remain: are the connections anecdotal or structural? In which terrorist activities are smugglers involved (getting terrorists across borders? Transporting weapons? Providing funding through smuggling of illegal goods? Using commercial fraud to generate extra profits that are invested in terrorist activities? What are the processes that lead smugglers to become involved in terrorist activities? If these questions are not addressed, we run the risk of considering all smugglers as potential terrorists, and deserving the same level of state force as terrorists. Nevertheless, those who are not involved in terrorist activities can be considered as potential allies of security services - for intelligence purposes, due to their knowledge of the territory and their capacity to infiltrate illegal activities. The systematic linkage between smuggling and terrorism is based on economic reasoning, and ignores the ideological dimension of terrorism: some smugglers we met during the mission are strongly ideologically opposed to the terrorists' political objectives and religious convictions.

Finally, borders and cross-border trade could potentially be considered a wealth creation tool leading to conflict resolution. As an example, border activities could offer a solution in a postconflict period by involving former fighters in licit economic activities. ${ }^{12}$ As the fighters' own vehicles (such as four-wheel drive pick-ups) are suitable in many cases to transport goods during a post-conflict period, governments can offer them some opportunities to use their vehicles for commercial purposes. 


\section{Appendix ${ }^{13}$}
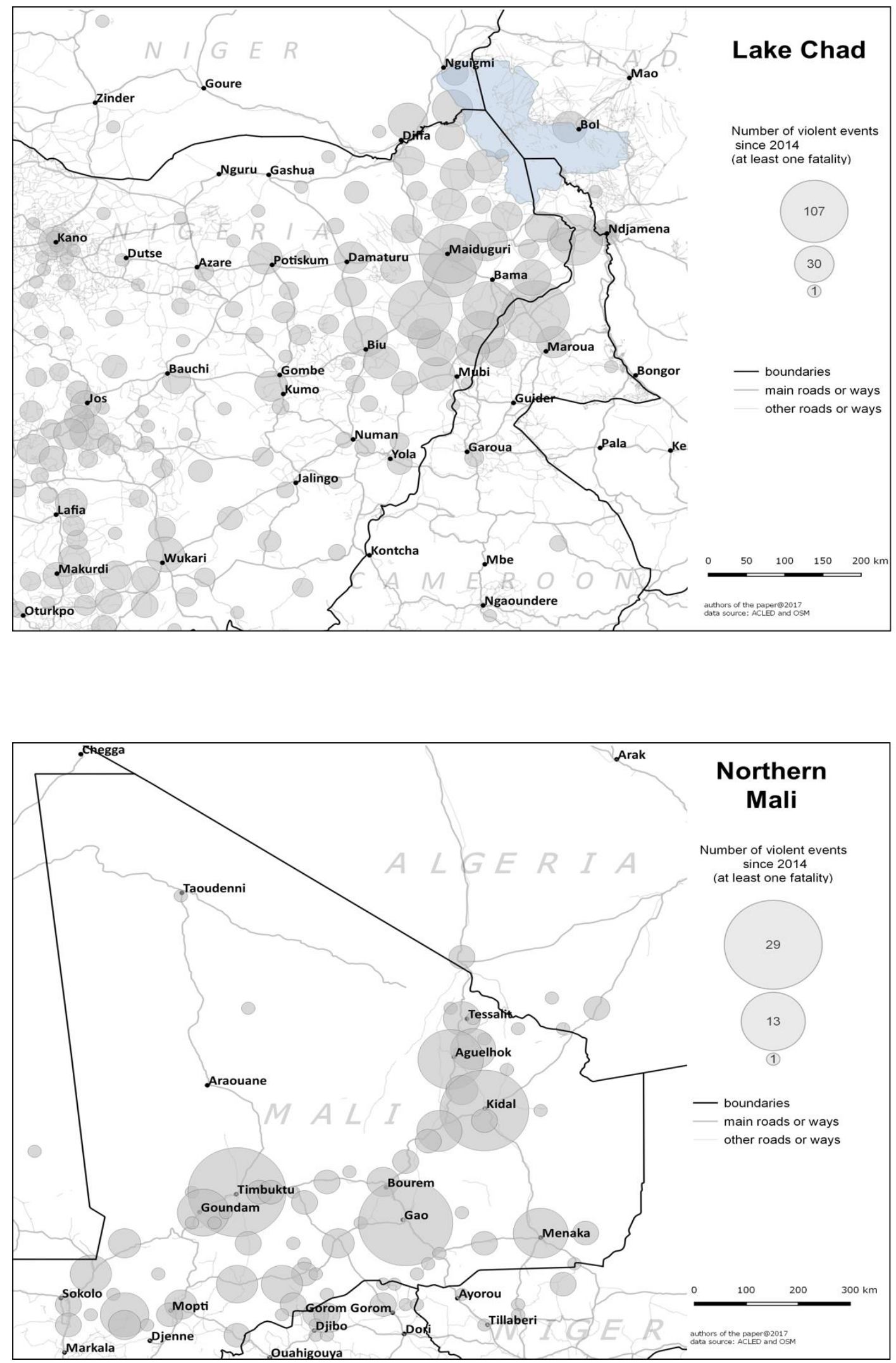

13 Sources of data for mapping the events are the Armed Conflict Location and Event Data database (ACLED, Raleigh 2010) and the OpenStreetMap project. 

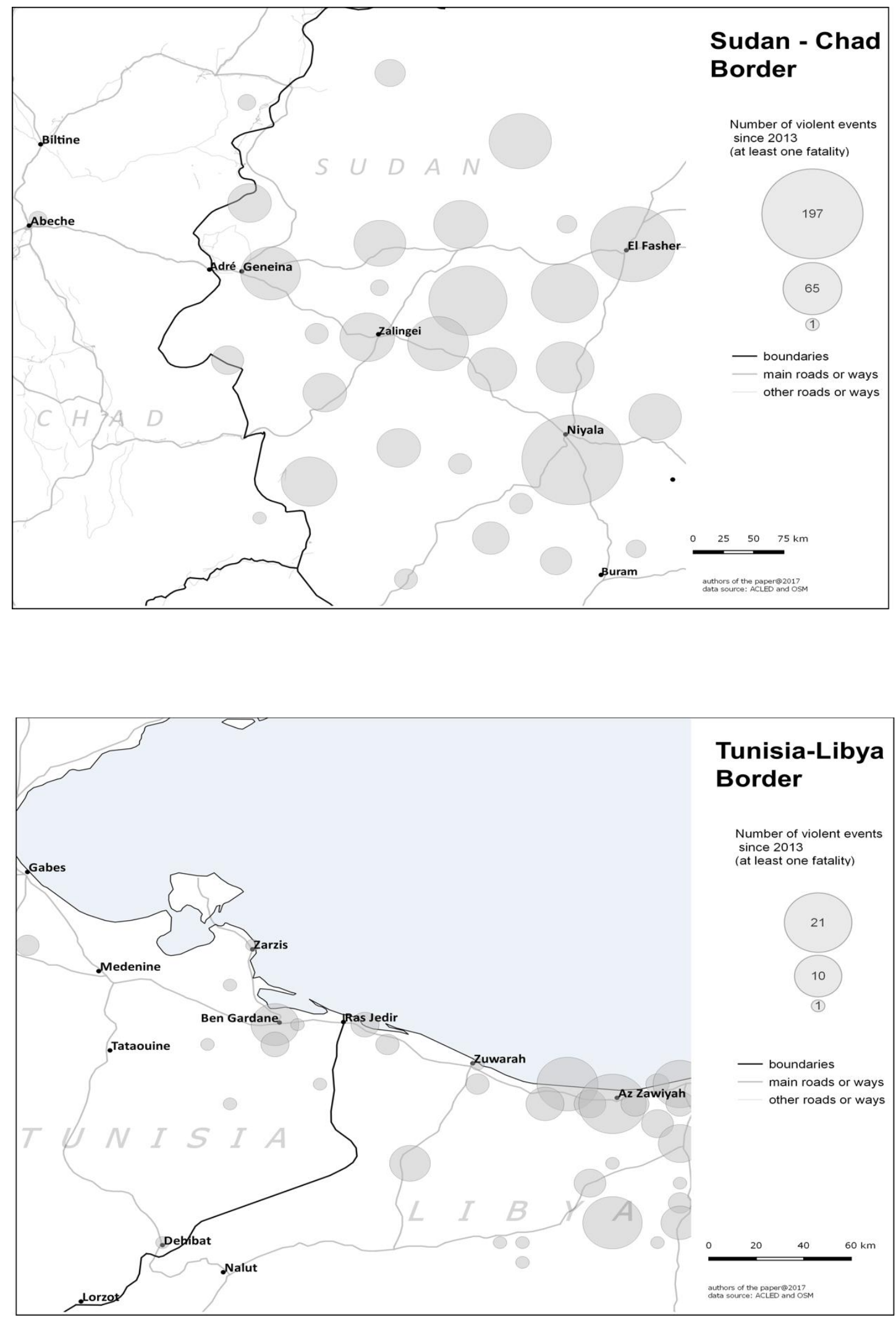


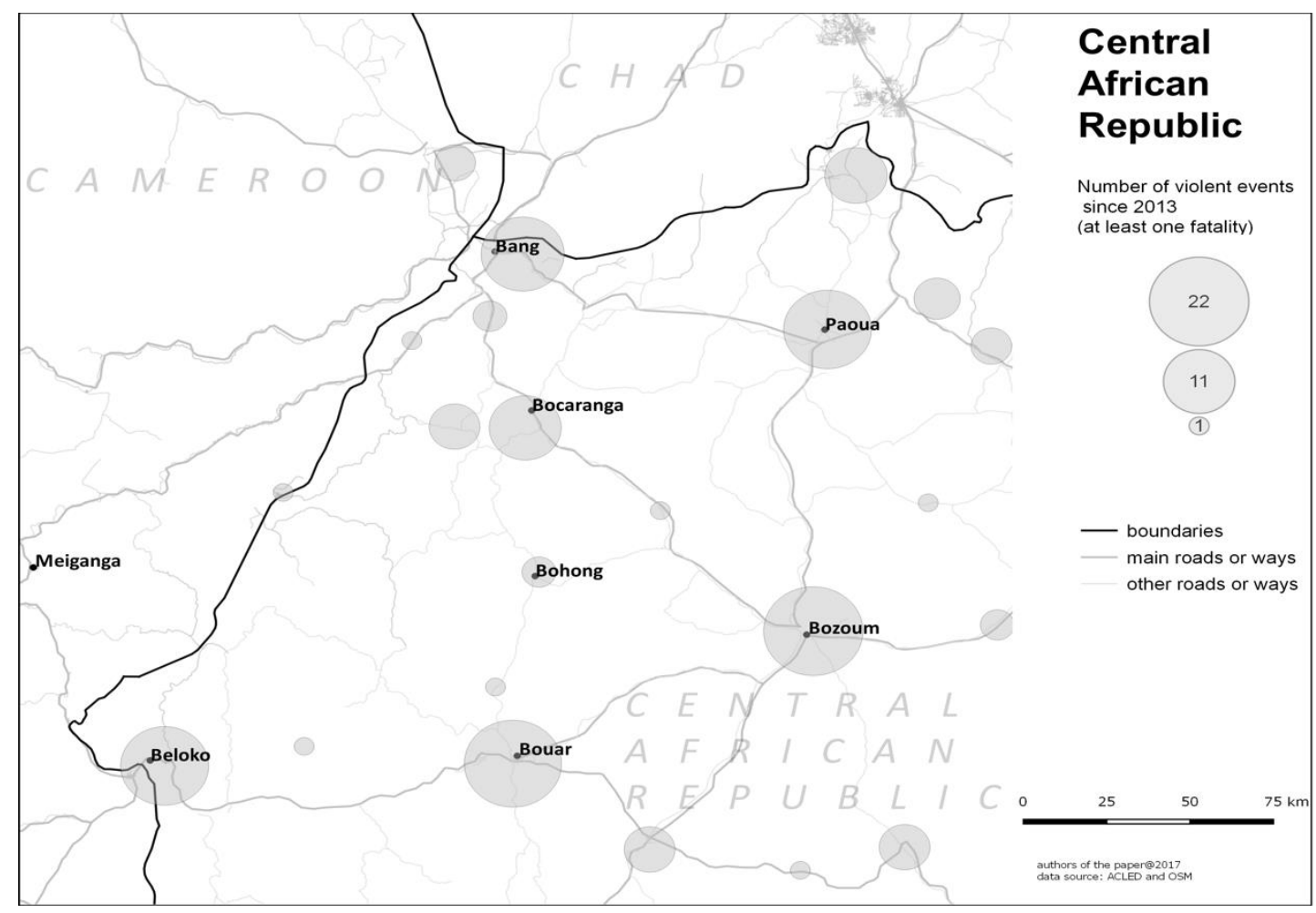




\section{References}

Amin, M. and Hoppe, M. (2013) Where Informal Procedures are Quasi-Formal - CrossBorder Trade between West and Central Africa, Africa Trade Policy Note 37, Washington DC: World Bank

Ayadi, L., Benjamin, N., Bensassi, S. and Raballand, G. (2014) 'An Attempt to Estimating Informal Trade Across Tunisia's Land Borders', Articulo - Journal of Urban Research [Online], 10, <http://articulo.revues.org/2549>

Bensassi, S., Brockmeyer, A. Pellerin, M. and Raballand, G. (forthcoming) 'Algeria-Mali Trade: The Normality of Informality', Middle East Development Journal

Brenton, P., Portugal-Perez, A. and Regolo, J. (2014) Food prices, road infrastructure, and market integration in Central and Eastern Africa, Policy Research Working Paper Series 7003, The World Bank

Cantens, T. (2015) 'Un scanner de conteneurs en «Terre Promise» camerounaise: adopter et s' approprier une technologie de contrôle', L'Espace Politique. Revue en ligne de géographie politique et de géopolitique (25)

_ (2013) 'Other People's Money and Goods: The Relationship Between customs Officers and Users in Some Countries of Sub-Saharan Francophone Africa', Sociologus, 63(12): $37-58$

(2012) 'Is it possible to reform a customs administration: the role of bureaucratic elite in Cameroon?', in A. Amsden, A. DiCaprio and J. Robinson (eds), The Role of Elites in Economic Development, Oxford University Press

and Polner, M. (2016) 'Fighting Corruption in customs: Some Theoretical Insights and Empirical Lessons (1)', in R. Kęsek, M. Boroda and Z. Jóźwik (eds), Addressing Security Risks at the Ukrainian Border Through Best Practices on Good Governance, NATO Science for Peace and Security Series 129

_ _ and Raballand, G. (2016) Fragile Borders: rethinking borders and insecurity in Northern Mali, Global Initiative against Transnational Organized Crime

— Ireland, R. and Raballand, G. (2015) 'Introduction: borders, informality, international trade and customs', Journal of Borderlands Studies, 30(3): 365-380

_ Raballand, G. and Bilangna, S. (2010) 'Reforming Customs by measuring performance: a Cameroon case study', World Customs Journal 4(2): 55-74

Chalfin, B. (2010) Neoliberal frontiers: An ethnography of sovereignty in West Africa, University of Chicago Press

_ (2008) 'Sovereigns and citizens in close encounter: Airport anthropology and customs regimes in neoliberal Ghana', American Ethnologist 35(4): 519-538

(2004) 'Border scans: Sovereignty, surveillance and the customs service in Ghana', Identities: Global Studies in Culture and Power 11(3): 397-416 
Golub, S. (2015) 'Informal Cross-Border Trade and Smuggling in Africa', in O. Morrissey, R. A. Lopez and K. Sharma (eds), Handbook On Trade And Development, Edward Elgar

Jost, P. and Sandhu, H. (2003) The Hawala Alternative Remittance System and Its Role in Money Laundering, <https://www.treasury.gov/resource-center/terrorist-illicitfinance/Documents/FinCEN-Hawala-rpt.pdf>

Klem, B. (2012) 'In the Eye of the Storm: Sri Lanka's Front-Line Civil Servants in Transition', Development and Change, 43(3): 695-717

Lacher, W. (2012) Organized Crime and Conflict in the Sahel-Sahara Region, Carnegie Endowment for International Peace

La Porta, R. and Shleifer, A. (2014) 'Informality and Development', Journal of Economic Perspectives, 28(3): 109-126

Luckham, R. and Kirk, T. (2012) Security in hybrid political contexts: an end-user approach. JSRP Paper 2, Justice and Security Research Programme, International Development Department, London: London School of Economics and Political Science

Meagher, K. (2012) 'The Strength of Weak States? Non-State Security Forces and Hybrid Governance in Africa', Development and Change 43(5): 1073-1101

Michailof, S. (2015) Africanistan, Paris: Fayard

Moore, M. (2007) How does taxation affect the quality of governance?, IDS Working Paper Series 280, Brighton: Institute of Development Studies

Raballand, G. and Rajaram, A. (2013) Behavioral Economics and Public Sector Reform: An Accidental Experiment and Lessons from Cameroon, World Bank Policy Research Working Paper 6595, Washington DC: World Bank

Raeymaekers, T. (2010) 'War and the Transformation of Regulation on the Congo-Ugandan Border', Development and Change 41(4): 563-587

Raleigh, C., Linke, A., Hegre, H. and Karlsen, J. (2010) 'Introducing ACLED-Armed Conflict Location and Event Data', Journal of Peace Research 47(5): 651-660

Roitman, J. (2007) 'The Right to Tax: Economic Citizenship in the Chad Basin', Citizenship Studies 11(2): 187-209

Reyntjens, F. (2014) 'Regulation, taxation and violence: the state, quasi-state governance and cross-border dynamics in the Great Lakes Region', Review of African political economy 41(142): 530-544

Schulz, K. (2015) 'Borders, Conflict, and Trade', Annual Review of Political Science 18:125145

Sugget, N. (2015) See the Road Well. Shaping East Timor's Frontier, Pandanus Books, The Australian National University

Titeca, K. and Flynn, R. (2014) 'Hybrid Governance, Legitimacy, and (II)legality in the Informal Cross-Border Trade in Panyimur, Northwest Uganda', African Studies Review 57: $71-91$ 
Walther, O. (2015) 'Business, Brokers and Borders: The Structure of West African Trade Networks', The Journal of Development Studies 51(5): 603-620

- (2009) 'A Mobile Idea of Space. Traders, Patrons and the Cross-Border Economy in Sahelian Africa', Journal of Borderlands Studies 24 (1): 34-46 